\title{
Uterine rupture at the University of Calabar Teaching Hospital, Calabar; Nigeria: a six-year review
}

\author{
Patience O. Odusolu, Praise A. Uduigwomen*, Edu M. Eyong, \\ Komommo O. Okpebri , John J. Egbe
}

Department of Obstetrics and Gynaecology; University of Calabar Teaching Hospital, Calabar, Nigeria

Received: 30 December 2021

Accepted: 31 January 2022

\section{*Correspondence:}

Dr. Praise A. Uduigwomen,

E-mail: doctorpraiz@yahoo.com

Copyright: (c) the author(s), publisher and licensee Medip Academy. This is an open-access article distributed under the terms of the Creative Commons Attribution Non-Commercial License, which permits unrestricted non-commercial use, distribution, and reproduction in any medium, provided the original work is properly cited.

\begin{abstract}
Background: Ruptured uterus is one of the major complications of labour which contributes significantly to maternal and perinatal morbidity and mortality in low-resource and developing countries. Periodic review is necessary to determine the magnitude, risk factors and feto maternal outcomes to aid to plan prevention reduce maternal and fetal mortality are needed. The objective of the study was to determine the prevalence, risk factors, management options, and feto-maternal outcomes of uterine rupture in University of Calabar Teaching Hospital (UCTH), Calabar.

Methods: Records of women with uterine rupture between January 2013 and December 2018 were retrieved. Sociodemographic data, clinical presentations, surgical options, fetal and maternal outcomes were recorded and analysed. Data was presented in frequencies and percentages.

Results: During the study period, total number of deliveries was 11,382 with 41 ruptured uterus giving it an incidence of 0.36 percent. Twenty-eight $(71.8 \%)$ of the patients were unbooked while $11(28.2 \%)$ were booked. The mean age was 28.08 and majority were para 2 and 3 at 10 (25.6\%). Obstructed labour was the commonest cause $28(71.8 \%)$. Rupture of scar contributed to 8 cases $(20.5 \%)$. Commonest presentation was abdominal pain 25 (64.1\%). The commonest surgical procedure was uterine repair alone $21(53.8 \%)$, while repair and bilateral tubal ligation was 8 $(20.5 \%)$ and hysterectomy $9(23.1 \%)$. Maternal mortality was $1(2.6 \%)$ while fetal mortality was $32(82.05 \%)$. The cause of maternal death was anaemic heart failure.

Conclusions: Predisposing factors for uterine rupture at UCTH, Calabar are mostly modifiable. As such integrated efforts to prevent occurrence and ensure prompt management to reduce maternal and fetal mortality are needed.
\end{abstract}

Keywords: Uterine rupture, Obstructed labour, Maternal mortality, Perinatal mortality

\section{INTRODUCTION}

Ruptured uterus is one of the major life-threatening complications in obstetrics. It is the leading indication for emergency peripartum hysterectomy in low-income countries and is associated with high maternal and perinatal morbidity and mortality. ${ }^{1}$ Uterine rupture is a catastrophic event that occurs during pregnancy and childbirth. It is defined as a breach of myometrial wall integrity. ${ }^{2,3,5}$ The incidence of ruptured uterus differs between the developed and developing countries and may differ within the same country. ${ }^{3}$

Uterine rupture remains a public health concern in subSaharan Africa, although it is now rare in the developed world. The higher incidence in Sub-Saharan Africa has been attributed to sub-standard obstetric care, poor accessibility and availability of comprehensive emergency obstetric care facilities, illiteracy, traditional practices and cultural beliefs, poverty, poor socioeconomic status, 
dwindling health care funding and reluctance of the illiterate masses to accept even the limited services available. ${ }^{7,8,16}$ Uterine rupture in developed countries mostly occur secondary to previous caesarean section. Use of uterotonics and trial of labour on a scarred uterus are likely causes here. ${ }^{16}$ In a complete rupture, there is full thickness separation of the uterine wall and overlying visceral peritoneum, with the expulsion of the foetus and/or placenta into the abdominal cavity, whereas in incomplete rupture, the overlying serosa or visceral peritoneum is spared, it is frequently due to a dehiscence of a caesarean scar and usually uncomplicated. ${ }^{1,2,3,12}$ The cases studied here are those of complete rupture.

Risk factors for uterine rupture include congenital uterine anomalies (such as pregnancy in undeveloped uterine horn), feto pelvic disproportion, multiparity, pregnancy in elderly women, teenage pregnancy, unwise use of uterotonics for induction/augmentation of labour, placental abnormalities (placenta increta or percreta), previous uterine scars (deep cornual resection, myomectomy, metroplasty, previously repaired uterine rupture, hysterotomy, caesarean section), trial of labour after caesarean section, fetal macrosomia, prolonged/obstructed labour, unsupervised/neglected labour, abnormal lie/presentation, uterine instrumentation, grandmultiparity, chronic steroid use, use of herbs, cocaine, referral from another health center and distance travelled to hospital. Disorders of connective tissue can also affect the structure and function of the uterus. There are cases of uterine rupture reportedly associated with Ehlers-Danlos syndrome, but trauma contributes to only minority of cases of uterine rupture and is usually due to road traffic accident or assault. Other causes are external cephalic version, internal podalic version, difficult forceps, embryotomy, breech extraction, manual removal of placenta, adenomyosis, trophoblastic diseases such as invasive mole or choriocarcinoma and sacculation of entrapped retroverted uterus. ${ }^{1,2,6,7,12,15,16}$

Maternal case fatality rates as high as $10.3 \%$ to $16.0 \%$ has been reported while the fetal mortality rates are even much higher at $70.0 \%$ to $90.0 \%$. Mothers that escape death may have morbidities like anaemia, wound and genital sepsis and burst abdomen. Others may lose their uterus and compromise their future fertility. ${ }^{8}$

This study aims to determine the prevalence of uterine rupture, associated risk factors, clinical presentations, associated maternal and perinatal mortalities. These findings will facilitate improved management and better the obstetric outcome of patients with uterine rupture and those at risk, thereby reducing perinatal and maternal morbidity and mortality.

\section{METHODS}

This was a retrospective study of patients who had uterine rupture at University of Calabar Teaching Hospital (UCTH), Calabar over a six-year period, between January
2013 and December 2018. The folder numbers were extracted from the delivery and obstetric theatre registers and the folders retrieved from Medical Records Department of the hospital after due permission was sought and obtained. Out of the 11,382 deliveries, 41 cases of uterine rupture were recorded and only 39 folders were retrieved, and this formed the basis for the analysis.

Information on age, parity, risk factors, clinical presentations, type of uterine rupture, surgical procedures carried out, associated maternal morbidity and mortality and fetal outcome were extracted.

\section{RESULTS}

Out of the total 11,382 deliveries within the study period, 41 were uterine rupture giving a prevalence of 1 in 277 or 0.36 percent.

Table 1: Socio-demographic data of patients with uterine rupture.

\begin{tabular}{|lll|}
\hline Age (years) & Frequency & Percentage \\
\hline $\mathbf{1 6 - 2 0}$ & 3 & 7.7 \\
\hline $\mathbf{2 1 - 2 5}$ & 7 & 17.9 \\
\hline $\mathbf{2 6 - 3 0}$ & 18 & 46.15 \\
\hline $\mathbf{3 1 - 3 5}$ & 10 & 25.65 \\
\hline $\mathbf{3 6 - 4 0}$ & 1 & 2.6 \\
\hline Parity & & \\
\hline 0 & 1 & 2.6 \\
\hline 1 & 9 & 23.1 \\
\hline 2 & 10 & 25.6 \\
\hline 3 & 10 & 25.6 \\
\hline 4 & 3 & 7.7 \\
\hline Above 4 & 6 & 15.4 \\
\hline Booking status & & \\
\hline Booked & 11 & 28.2 \\
\hline Unbooked & 28 & 71.8 \\
\hline Educational status & \\
\hline $\begin{array}{l}\text { No formal } \\
\text { education }\end{array}$ & 3 & 7.7 \\
\hline Primary & 9 & 23.1 \\
\hline Secondary & 20 & 51.3 \\
\hline Tertiary & 7 & 17.9 \\
\hline Total & 39 & 100 \\
\hline & & \\
\hline
\end{tabular}

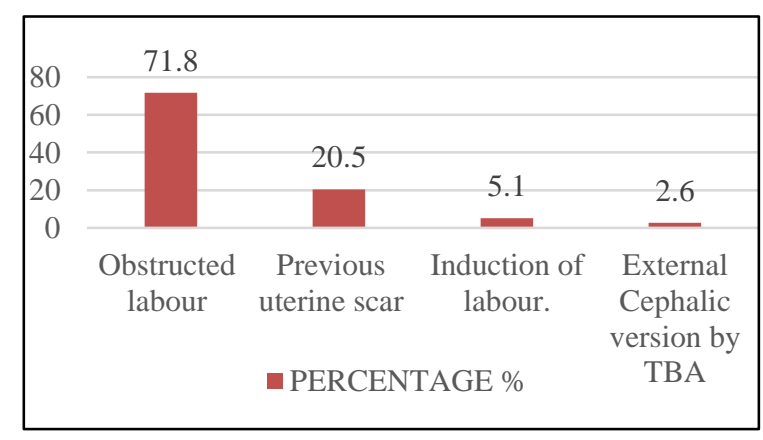

Figure 1: Aetiological risk factors. 
Table 1 shows the socio-demographic profile of patients with uterine rupture.

The commonest age group was 26-30 years $18(46.1 \%)$ while the least age group was $36-40$ years $1(2.6 \%)$. The mean age was 28.08 years. Uterine rupture was highest among those who were para 2 and para 3, at $10(25.6 \%)$ each followed by para one, $9(23.1 \%)$ while those more than para 4 were $6(15.4 \%)$ and the least were nulliparous $1(2.6 \%)$. Twenty-eight $(71.8 \%)$ of the patients were unbooked while $11(28.7 \%)$ of these patients booked for antenatal care. Among these patients, 3 (7.7\%) had no formal education, $9(23.1 \%)$ had primary education, 20 $(51.3 \%)$ had secondary education and 7 (17.9\%) had tertiary education.

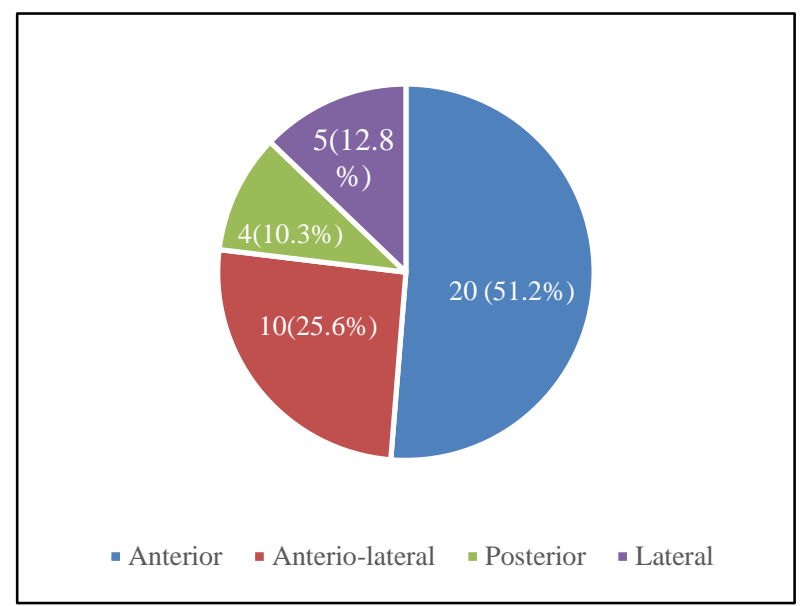

Figure 2: Site of uterine rupture.

Table 2: Clinical presentation of patients with uterine rupture.

\begin{tabular}{|lll|}
\hline $\begin{array}{l}\text { Clinical features } \\
\text { Vaginal bleeding + } \\
\text { abdominal pain }\end{array}$ & 5 & 12.8 \\
\hline $\begin{array}{l}\text { Abdominal pain and } \\
\text { tenderness only }\end{array}$ & 25 & 64.1 \\
\hline $\begin{array}{l}\text { Cessation of } \\
\text { contraction + No } \\
\text { fetal movement }\end{array}$ & 3 & 7.7 \\
\hline $\begin{array}{l}\text { Abdominal } \\
\text { tenderness and fetal } \\
\text { distress }\end{array}$ & 4 & Percentage \\
\hline $\begin{array}{l}\text { Anaemic heart } \\
\text { failure + Shock }\end{array}$ & 1 & 10.2 \\
\hline $\begin{array}{l}\text { Coils of gut per } \\
\text { vagina }\end{array}$ & 1 & 2.6 \\
\hline Total & $\mathbf{3 9}$ & $\mathbf{1 0 0 . 0}$ \\
\hline
\end{tabular}

Table 2 shows the pattern of clinical presentation of patients with uterine rupture. Common modes of presentations included abdominal pain and tenderness only
$25(64.1 \%)$, vaginal bleeding and abdominal pain 5 $(12.8 \%)$ and abdominal pain with fetal distress 4 (10.2\%).

Other symptoms were cessation of contraction and perception of fetal movement $3(7.7 \%)$, one patient presented in shock with anaemic heart failure $(2.6 \%)$ and one patient $(2.6 \%)$.

Table 3: Surgical procedures performed.

\begin{tabular}{|lll|}
\hline $\begin{array}{l}\text { Surgical } \\
\text { procedure }\end{array}$ & Frequency(n) & Percentage \\
\hline Repair alone & 21 & 53.8 \\
\hline $\begin{array}{l}\text { Repair and } \\
\text { BTL }\end{array}$ & 8 & 20.5 \\
\hline Hysterectomy & 9 & 23.1 \\
\hline $\begin{array}{l}\text { Death before } \\
\text { intervention }\end{array}$ & 1 & 2.6 \\
\hline Total & $\mathbf{3 9}$ & 100.0 \\
\hline
\end{tabular}

Table 4: Complications.

\begin{tabular}{|lll|}
\hline $\begin{array}{l}\text { Complication } \\
\text { Wound } \\
\text { sepsis }\end{array}$ & 6 & 15.4 \\
\hline $\begin{array}{l}\text { Post op } \\
\text { Anaemia }\end{array}$ & 21 & 53.8 \\
\hline $\begin{array}{l}\text { Entero - } \\
\text { cutaneous } \\
\text { fistula }\end{array}$ & 1 & 2.6 \\
\hline $\begin{array}{l}\text { Maternal } \\
\text { mortality }\end{array}$ & 1 & 2.6 \\
\hline Still birth & 32 & 82.1 \\
\hline $\begin{array}{l}\text { Blood } \\
\text { transfusion }\end{array}$ & 31 & 79.5 \\
\hline
\end{tabular}

Table 3 shows the aetiological risk factors. Seven (17.9\%) of the patients had previous uterine scars while $28(71.7 \%)$ had obstructed labour without uterine scar.

Figure 1 shows the site of rupture. Anterior uterine rupture was the commonest $20(51.3 \%)$, anterolateral uterine rupture was $10(25.65 \%)$ while the posterior rupture was 4 $(10.25 \%)$.

Table 4 shows the surgical procedures performed. The commonest procedure was uterine repair alone 21 $(53.8 \%)$, while the least was repair and bilateral tubal ligation $8(20.5 \%)$.

Table 5 shows the maternal and perinatal mortality among patients with uterine rupture.

There was $1(2.6 \%)$ maternal death. Stillbirth were 32 $(82.05 \%)$. Among patients with uterine rupture, 31 $(79.5 \%)$ had blood transfusion, $21(53.8 \%)$ patients had anaemia post operatively, while $6(15.4 \%)$ had wound sepsis. The one patient who presented with coils of gut per 
vagina had enterocutaneous fistula post operatively. Some patients had more than one complication.

\section{DISCUSSION}

The prevalence of ruptured uterus in this study is 1 in 277 deliveries. This prevalence however was lower 1 in 202 in Bida, North central Nigeria. ${ }^{10}$ It was also lower 1 in 41 in an Ethopian study and Uganda 1 in $131 .^{15,16}$ It was also lower with 1 in 172 in Benin,7 1 in 119 in Anambra, 1 in 164 deliveries in Lagos4 and 1 in 120 in Azare, Northeast Nigeria. ${ }^{8,9}$ It was however higher with 1 in 290 deliveries recorded in Bauchi, Nigeria. ${ }^{3}$ In the index study, the high prevalence is a reflection of poor utilization of obstetric facilities in our environment.

The above prevalence is in sharp contrast from values from developed countries, and other countries with good and accessible maternity care services. A health facility in the UK which has an annual delivery rate of 6000 births reported 12 cases of uterine rupture over a 6-year period with a prevalence of 12 in 36,000 births, whereas a national review reported an incidence of $0.2 / 1000$ deliveries.10,12. Historically, there is variation in global incidence of uterine rupture with higher morbidity and mortality rates predominantly in developing countries. ${ }^{6}$ There is also variable incidence in different parts of the country. ${ }^{3}$

The difference between incidences in developing countries as compared to developed countries is very wide. The variation may most likely be due to local differences in presentation and available obstetric services. These include availability, access, utilization and quality of maternal services in the area. Many low resource countries have not performed fairly relative to the availability of skilled obstetricians and quality maternal services. When obstetric services are available, reports show poor attitude and uptake among women who suffer uterine rupture. ${ }^{8,10}$ Other factors responsible for the high incidence in developing countries relate to poverty, low literacy levels, potentially harmful cultural and religious practices, poor transportation and communication systems, not registering for antenatal care and high level of patronage of spiritual churches for pregnancy and child birth care..$^{7,14,16}$ These factors continue to increase the incidence of ruptured uterus in developing countries. It was also found that the majority of these patients in this study were unbooked $(71.8 \%)$, this is comparable to the figures from other parts of the country and other countries in Sub-sahara Africa. $4,5,7,8$

The parity distribution was similar to studies in Lagos and Anambra where women who had delivered 1-3 times before, constituted the majority of women with ruptured uterus. $^{4,5} 25.65 \%$ of patients had parity of two; also $12.8 \%$ of the patients were primiparous, while $20.5 \%$ of patients had parity of four. $2.6 \%$ of them was nulliparous and $12.8 \%$ of them were para five and grand multiparous. This shows that primigravidas are not immune to rupture though uterine rupture is usually associated with grandmultiparity. ${ }^{1,5,13}$ This is in consonance with findings in Northern Nigeria. ${ }^{3,10}$ This also calls for caution in the use of oxytocics in induction and augmentation of labour in nulliparous women.

Most of the women were from the lower socioeconomic groups as evidenced by their level of education. This agrees that ignorance and poverty contribute greatly to the high incidence of ruptured uterus seen in developing countries including Nigeria. ${ }^{11,14,16}$ There exist some variations in the aetiological classification of ruptured uterus by different authours. ${ }^{1}$ The commonest risk factors for ruptured uterus in this study were obstructed labour without a previous scar $19(48.7 \%)$, followed by obstructed labour due to malpositions malpresentations/foetal macrosomia 9 (23.0\%) and previous scar 7 (17.9\%). In contrast, studies done at Lagos and Nnewi show that scarred uterus contributed significantly to $32.84 \%$ and $67.74 \%$ respectively. ${ }^{4,5}$

The predominance of obstructed labour, multiparity and previous scar in this study is comparable to a study in South-south Nigeria where the major risk factors were multiparity, previous scar and prolonged labour. ${ }^{7}$ Other risk factors in this study included misoprostol induced labour, oxytocin augmentation of labour, external cephalic version at a traditional birth attendant's and fetal macrosomia/malpresentations which are all documented risk factors. ${ }^{11,12,13}$ As was in Bida, Northcentral Nigeria, the commonest modes of presentation in this study were abdominal pain with tenderness and bleeding per vagina with abdominal pain. ${ }^{10}$ This may have resulted owing to the fact that most patients presented late. , $^{70,15}$

No consensus has been reached as to the best surgical option that should be used. ${ }^{1}$ The surgical option chosen should be individualized, depending on the anatomy of the rupture, the condition of the patient and the skill of the surgeon. The procedure performed should be short, safe and yet feasible in that particular case. ${ }^{1,10,1} 2$ The need for reproductive function should also be taken into consideration. ${ }^{4,12}$

In this study, repair alone was the commonest surgical operation. This compares with studies in Nnewi, and Abia but is in contrast with studies in Lagos and Bauchi where repair with bilateral tubal ligation was the commonest done. $^{3-6}$ This was followed by subtotal hysterectomy. This may be due to the fact that majority of the patients were of low parity and in most cases of lower segment, anterior ruptures; repair was considered as they were still desirous of future pregnancies. These patients should however be warned of the increased risk of rupture in subsequent pregnancies, advised on the option of permanent contraception and the need to have a planned elective caesarean delivery ( 37 to 38 weeks) if they chose to carry future pregnancies. ${ }^{12}$ The case fatality rate for ruptured uterus for the mothers in this study was $2.6 \%$, and this compares with $2.2 \%$ in Benin. ${ }^{7}$ This is however much 
lower than $6.6 \%$ in a study in Ethiopia16, $10.7 \%$ in Azare, Northeast Nigeria, $11.94 \%$ in Lagos and $13.4 \%$ in Bauchi. $^{3,4,9}$ The fetal mortality rate was high $82.05 \%$, which compares with $88.4 \%$ in Anambra8, $87.5 \%$ in Bida, Northcentral Nigeria and $100 \%$ in Bauchi. ${ }^{3,10}$ This is in sharp contrast to figures in developed countries where the maternal mortality and fetal mortality were even below $1.0 \% .^{5,10}$

The commonest site of injury was in the anterior part of the uterus. This is in consonance with findings by Danso and in a study in Abia, Nigeria. ${ }^{1,6}$ The post-operative complications included anaemia, wound sepsis, genital sepsis and enterocutaneous fistula. These are all documented complications from other studies of uterine rupture. . $^{1,2,3,10}$

\section{CONCLUSION}

Uterine rupture constitutes a major obstetric problem at University of Calabar Teaching Hospital, Calabar. The prevalence of ruptured uterus can be reduced drastically by health education, uptake of antenatal care, careful selection of patients for trial of labour after caesarean section, skilled attendance in labour and provision of emergency obstetric care services and facilities that are accessible and affordable.

Funding: No funding sources Conflict of interest: None declared

Ethical approval: The study was approved by the Institutional Ethics Committee

\section{REFERENCES}

1. Danso KA. Ruptured Uterus. In: Comprehensive Obstetrics in the Tropics. Kwawukume EY, Ekele BA, Danso KA, Emuveyan EE (Eds). 2nd Ed. Assemblies of God Literature Center, Accra. 2015;114-20.

2. Carrillo AP, Chandraharan E. Rupture of the uterus. In: Best Practice in Labour and Delivery. Arullumaran $S$ (Ed). 2nd Ed. Cambridge University Press. 2016;293-300.

3. Aliyu LD, Elnafaty AU, Kadas SA, Dattijo LM, Aminu BM. Uterine rupture an obstetrics catastrophe: incidence, risk factors, management and outcome at Abubakar Tafawa Balewa University Teaching Hospital, Bauchi, Nigeria. Trop J Obstet Gynaecol. 2012;29(1):13-17.

4. Adegbola O, Odeseye AK. Uterine rupture at Lagos University Teaching Hospital. J Clin Sci. 2017;14:137.
5. Mbamara SU, Obiechina N, Eleje GU. An analysis of uterine rupture at the Nnamdi Azikiwe University Teaching Hospital Nnewi, South east Nigeria. Niger J Clin Pract. 2012;15:448-52.

6. Eguzo KN, Lawal AK, Ali F, Umezurike CC. Patterns of uterine rupture in Nigeria: a comparative study of scarred and unscarred uterus. Int J Reprod Contracept Obstet Gynaecol. 2015;4:1094-9.

7. Osemwenkha PA, Osaikhuwuomwan JA. A 10-year review of uterine rupture and its outcome in the University of Benin Teaching Hospital, Benin City. Niger J Surg Sci. 2016;26:1-4.

8. Igwegbe AO, Eleje GU, Udegbunam OI. Risk factors and perinatal outcome of uterine rupture in a lowresource setting. Niger Med J. 2013;54:415-9.

9. Dattijo LM, Umar NI, Yusuf BM. Ruptured uterus in Azare, North Eastern Nigeria. Jos Journal of Medicine. 2008;5(2):17-20.

10. Adewale FB, Adeniran AS, Ijaiya MA. Clinical profile of patients with uterine rupture at a tertiary facility in North-central Nigeria. Port Harcourt Med J. 2019;13:32-6.

11. Motomura K, Ganchimeg T, Nagata C, Ota E, Vogel JP, Betran AP et al. Incidence and outcomes of uterine rupture among women with prior Caesarean section: WHO Multi-country Survey on Maternal and Newborn Health Sci Rep. 2017;7:44093.

12. Dutta A. Management of ruptured uterus. In: Mid Essex Hospital Services; Clinical Guidelines No. 2017;04243:2017.

13. WHO Systematic review of maternal mortality and morbidity: the prevalence of uterine rupture. BJOG: An International Journal of Obstetrics and Gynaecology. 2005;112:1221-8.

14. Etuk SJ, Abasiattai AM, Ande AB, Omo-Aghoja L, Bariweni AC, Abeshi SE et al. Maternal near-miss and death among women with rupture of the gravid uterus: a secondary analysis of the Nigeria near-miss and Maternal Death survey. BJOG: an International Journal of Obstetrics and Gynaecology. 2019;126(s3).

15. Jonathan PN. Posterior uterine rupture secondary to use of herbs leading to peritonitis and maternal death in a primigravida following vaginal delivery of a live baby in Western Uganda: a case report. The Pan African Medical Journal. 2016;23:81.

16. Astatikie G, Limenih MA, Kebede M. Maternal and fetal outcomes of uterine rupture and factors associated with maternal death secondary to uterine rupture. BMC Pregnancy and Childbirth. 2017;117.

Cite this article as: Odusolu PO, Uduigwomen PA, Eyong EM, Okpebri KO, Egbe JJ. Uterine rupture at the University of Calabar Teaching Hospital, Calabar; Nigeria: a six year review. Int J Reprod Contracept Obstet Gynecol 2022;11:709-13. 